\title{
The language, identity and culture of ethnic minorities in the Central European contexts
}

\author{
[Jazyk, identita a kultura etnickych minorit v stredoeuropskych \\ suvislostiach]
}

Ladislav Lenovsky

DOI: 10.18355/XL.2018.11.04.11

\begin{abstract}
Language and cultural diversity is a brand of Central Europe. The genesis and present existence of European nations, minorities and ethnographical groups is the origin result of specific historical processes and current trends. Slovaks as a nation with their own state, as well as minorities abroad; and the territory of Slovakia with its own minorities, are representatives of the Central European multicultural and multiethnic system, which consists of unique linguistic and ethnocultural entities. From the postOsmanic period (colonization and revitalization), through the national revival (disintegration of the monarchy) and the "reformatting" of Europe (national states), to the eurounionization and globalization trends, these communities are the mirror of general and specific influences that has so far been reflected in their unique identity, language and culture.
\end{abstract}

Key words: language, culture, identity, minority, Slovaks, Slovakia

\section{Anotácia}

Jazyková a kultúrna diverzita je charakterovou črtou strednej Európy. Vývoj a súčasné jestvovanie prítomných národov, minorít a etnografických skupín je originálnym výsledkom špecifických historických procesov aj aktuálnych trendov. Slováci ako národ s vlastným štátom, aj ako minority v zahraničí; a územie Slovenska s vlastnými minoritami, sú reprezentantmi stredoeurópskeho multikultúrneho a multietnického systému, ktorý pozostáva s jedinečných jazykových a etnokultúrnych entít. Od postosmanského obdobia (kolonizácia a revitalizácia), cez národné obrodenie (rozpad monarchie) a "preformátovanie" Európy (národné štáty), až po eurounionizačné a globalizačné trendy, sú tieto spoločenstvá zrkadlom všeobecných aj špecifických vplyvov, ktoré sa dodnes prejavujú v ich jedinečnej identite, jazyku a kultúre.

Kl'účové slová: jazyk, kultúra, identita, minorita, Slováci, Slovensko

\section{ÚVOD}

Národ je dôležitá jazyková, etnická, kultúrna, spoločenská a ešte stále aj politicko-ekonomická jednotka. Jazyková a etnická rozmanitost' Európy, konštituovaná do štátov etablovaných na národnom princípe spolu s legitimizáciou a inštitucionalizáciou národnostných minorít, etnických a etnografických skupín, je jej charakterovou črtou a jedinečným, i ked' niekedy bolestivým, výsledkom humanizmu vo svojej najrýdzejšej podobe. Národná, národnostná, etnická identita a občianska

XLinguae, Volume 11, Issue 4, October 2018, ISSN 1337-8384, eISSN 2453-711X 
príslušnost' sú jedny z najvýznamnejších identít, ktorými súčasný európsky človek disponuje. Niekedy neuvedomovane a latentne, inokedy manifestne a úmyselne ovplyvňujú najzávažnejšie otázky jeho života.

Slováci žijúci mimo územia Slovenska sú súčast'ou slovenského národa. Ich kultúra je súčast'ou kultúry Slovenska, aj slovenskej kultúry, ktorá sa bytostne neviaže na geografický priestor Slovenska. Ich jazyk je súčast’ou systému slovenského jazyka, aj ked' má vlastný život. Títo Slováci súčasne, ako príslušníci národnostných minorít, sú občanmi štátov, kde sa narodili, kde po generácie žijú, kde žili ich predkovia, kde je ich skutočný domov. Ich kultúra je neoddelitel'nou súčast'ou kultúry týchto štátov a ich jazyk je súčastou jazykového spektra týchto štátov. Ich kultúrna a jazyková identita je formovaná príslušnost'ou k národnej kultúre a jazyku, k regionálnej kultúre a jazyku (neraz pozostávajúcich z d’alších inoetnických jazykov a kultúr), príslušnost'ou ku kultúre a jazyku majority, aj ku kultúre európskej a v najširších kontextoch i svetovej.

Podobne etnicky rozmanité je aj územie Slovenska, kde žijú etablované etnické minority a etnografické skupiny s vlastnými konceptami kultúrneho dedičstva, inštitúciami, organizáciami, podujatiami a členskou základňou. Okrem národnostných skupín, ktoré sú súčast'ou svojich národov/štátov je potrebné venovat' pozornost' aj takým entitám založeným na etnickom princípe, ktoré doteraz neboli predmetom záujmu, boli marginalizované, alebo zanikajú. Jednou z takých etnických skupín sú Huncokári, drevorubači nemeckého pôvodu, ktorí sa usadili v Malých Karpatoch. Ich potomkovia sa dnes aktívne hlásia ku kultúrnemu dedičstvu svojich predkov, identifikujú sa s nimi a snažia sa o revitalizáciu.

Slováci južne od hranice Slovenska naopak, dodnes žijú v početných enklávach, aj $\mathrm{v}$ diasporicky pretrvávajúcich skupinách. Ich prítomnost' južne od územia Slovenska je výsledkom najmä post-osmanskej etapy vývoja RakúskoUhorska, následne vplyvov formovania Európy 20. storočia na princípe národných štátov (vrátane obidvoch svetových vojen, repatriácie, emigrácie a reemigrácie) a v súčasnosti aj projektu „novej“ Európy 21. storočia - multikultúrnej, globalizovanej, čoraz viac deetnizovanej, denacionalizovanej.

Stredoeurópske minority už po generácie prežívajú aj zanikajú pod vplyvom historickej turbulentnosti tohto priestoru, vo víchre „vel'kých“ geopolitických ideových, ekonomických a technologických trendov, vo vetre vnútroštátnych stratégií a nálad, ale aj v pnutiach a vibráciách endogénneho vývoja a vzt'ahov s bezprostredne obklopujúcim prostredím. Súčasné jestvovanie týchto komunít je preto nielen výsledkom historického vývoja (pomerne dobre prebádaného etnológiou, historiografiou, jazykovedou či vedami o umení ${ }^{1}$ ), ale odzrkadl'uje, absorbuje a zápasí aj s aktuálnymi vplyvmi - niekedy len d’alšími variantmi tradičných geopolitických a etnických procesov, inokedy s úplne novými globalizačnými, technologickými, sociokultúrnymi a ideovými procesmi. ${ }^{2}$

\footnotetext{
${ }^{1}$ K problematike bližšie napríklad: etnologické práce - Botík 2007, Divičanová 1996, 1999, Šatava 1994, 2013, historiografické práce - Kmet' 2010, 2011, 2012, 2013, Šutaj 2005, umenovedné práce - Babiak 2016, kulturologické práce - Kováčová 2011, 2014, sociolingvistické práce - Uhrinová 2006, 2008, Tušková 2010, 2011, 2016.

${ }^{2}$ Podl'a cenzov v jednotlivých krajinách bol stav v roku 2011 nasledovný (krajina, počet): Chorvátsko, 4.753 [Population by etnicity, by towns/municipalities, 2011]; Mad'arsko, 35.208
} 
Na rozdiel od Slovákov v Srbsku, Rumunsku, čiastočne i Chorvátsku a Mad'arsku, Huncokári vo svojej autochtónnej podobe už zanikli. Žije len ich odkaz, artefakty, spomienky, útržky špecifického jazyka, slovesného folklóru a gastronómie. I napriek tomu sa do niekol'kých občianskych združení sformovali skupiny ich potomkov, stretávajú sa, organizujú špecifické podujatia a realizujú stratégie na udržanie kontinuity, prípadne šírenia povedomia vo verejnej sfére a budovania minoritnej časti identity u svojej mladej generácie (Slobodová Nováková, 2017:6778).

Ciel'om príspevku je objasnit' vzt'ah medzi jazykom, identitou a kultúrou v prostredí etnických minorít v aktuálnych kontextoch strednej Európy na vybraných príkladoch slovenských komunít v Mad’arsku, Rumunsku, Srbsku, Chorvátsku a takmer (alebo už) zaniknutej minority nemeckých drevorubačov v Malých Karpatoch, ktoré sú predmetom revitalizačných aktivít. Materiál bol získaný terénnym výskumom v rokoch 2005-2018. ${ }^{3}$ Priebežne bol spracovávaný, analyzovaný a interpretovaný prostredníctvom čiastkových aj syntetických výstupov. Originálnost' prítomného príspevku spočíva vo vytvorení mozaiky na prvý pohl'ad rozmanitých príkladov z vybraných skúmaných komunít, ktorej ciel’om je odhalenie relevantných kontextov medzi minoritným jazykom, identitou a kultúrou, aktualizovaných cez aspekt revitalizácie.

\section{Dolná zem}

V súvislosti s etnogenézou slovenských komunít žijúcich južne od hranice súčasného Slovenska je dôležitou metodologickou, interpretačnou aj terminologickou otázkou definovanie Dolnej zeme. Dolná zem je špecifický kultúrno-historický a geografický priestor $\mathrm{v}$ Karpatskej kotline, v medziriečí Dunaja a Tisy. Od stredoveku tento pojem označoval centrálnu čast' Uhorska. Po rozpade monarchie v roku 1918 jeho politický význam zanikol. (Botík, Slavkovský, 1995) Územie Dolnej zeme pripadlo novovzniknutým štátom - Mad'arsku, Rumunsku a čiastočne Juhoslávii.

[National data 2017]; Rumunsko, 13.654 [Populatia dupa etnie la recensamintele 2017]; Srbsko, 52.750. [РЕЗУЛТАТИ ПОПИСА... 2016:14]

${ }^{3}$ Výskumné lokality boli: Mad’arsko - zadunajská dedina Jášt’ (Jásd) v oblasti Bakonského lesa, pilišský Senváclav (Pilisszentlászló), novohradský Veňarec (Vanyarc), pripeštianska Šára (Sári), dnes čast' mesta Dabaš (Dabas - Sári), podunajský Ed’ház (Dunaegyháza) a mesto Békešská Čaba (Békescsaba); Srbsko (autonómia Vojvodina) - báčske dediny Pivnica (Pivnice) a Silbaš (Silbaš), pribelehradské Bol'ovce (Boljevci) a banátska Vojlovica (Vojlovica), dnes čast' mesta Pančevo (Vojlovica - Pančevo); Rumunsko - mesto Nadlak (Nadlac) v aradskej oblasti, dedina v rumunskej časti Banátu Butín (Butin) a dve bihorské dediny Borumlak (Borumlaca) a Varzal' (Varzari) v Sedmohradsku. Chorvátsko reprezentuje dedina Sol’any (Soljani) v slavónskej časti Sriemu. (Lenovský, 2016, 2017)

Ciel'om výskumu bolo: 1. získat', zaznamenat', spracovat' a prezentovat' materiál o doteraz vôbec alebo málo preskúmaných slovenských komunitách a rozšírit' tak existujúce poznatky a 2.verifikovat' existujúce historické stereotypy o reprezentatívnosti lokality a konfrontovat' ich $\mathrm{s}$ aktuálnym stavom a reálnymi perspektívami prítomných slovenských minorít. V Mad'arsku išlo o týždňové jednorazové kolektívne výskumné pobyty, v Srbsku a Rumunsku o pobyty v dížke 7 - 10 dní, opakované tri-štyrikrát počas jedného roka v každej lokalite. V Chorvátsku o jeden dvojtýždňový pobyt.

XLinguae, Volume 11, Issue 4, October 2018, ISSN 1337-8384, eISSN 2453-711X 
Z kultúrno-historického hl'adiska „pod slovenskou Dolnou zemou rozumieme tie slovenské enklávy (osady, obce a agrárne mestá), ktoré vznikali v priebehu 18. a niektoré aj v priebehu 19. storočia južne od pomyselnej čiary Budapešt' - Miškovec - Nové Mesto pod Šiatrom, predovšetkým však v tzv. békešsko-čanádskej oblasti, Báčke, Srieme a Banáte." (Kmet', 2011:50) Z kultúrno-geografického hladiska ide o nížinné územie vymedzené Karpatskou kotlinou, typické miernym podnebím, dobrými hydrologickými podmienkami, mimoriadne vysokou bonitou pôdy, minimálnym geomorfologickým členením, nížinnou homogénnostou. (Chrastina 2006, 2009, 2012) Z pohl'adu kultúrnej ekológie je Dolná zem priestor „kultúry bieleho chleba“ - nížinné územie pestovania pšenice, kukurice, novšie sóje. Z etnologického hl'adiska za Dolnú zem neraz považujeme celé územie južne od hranice Slovenska osídlené Slovákmi, kedy do nej zahrňujeme aj slovensko-mad'arské pomedzie, Zadunajsko (na pravom brehu Dunaja), Zátisie (na l’avom brehu Tisy); autonómiu Vojvodinu; Bihorsko-salajskú oblast' a Bukovinu v Rumunsku; Slavóniu v Chorvátsku a pridunajské časti severného Bulharska. (K problematike Dolnej zeme bližšie napríklad Babiak, 2016, Botík, 2007, Divičanová, 1996, 1999.)

Najužšie vymedzenie Dolnej zeme používajú samotní Dolnozemci. Pojem Dolná zem dodnes pretrval v povedomí, jazyku a kultúre jeho obyvatel’ov (,náš dolnozemskí chl’ebík“; „,my dolnozemskí Slováci“; „,my Dolnozemci“; „,tu, na Dolnej zemi“ ap.). Za Dolnozemcov sa považujú len Slováci z územia juhovýchodného Mad’arska a severozápadného Rumunska (békešsko-čanádskej a aradsko-banátskej oblasti). Príbuzensky, jazykovo a kultúrne sú si ovel’a bližší ako s ostatnými slovenskými komunitami, lebo oficiálna hranica existuje len 100 rokov.

Nejednotné historické, geografické, kultúrne, etnické, hospodárskopolitické, spoločenské kritériá definovania tohto priestoru sa prelínajú v tom, že Dolná zem je historické územie osídlované v období 17. - 19. storočia stredoeurópskymi etnikami; špecifické a celistvé svojou nížinnou multietnickou a multikonfesionálnou kultúrou; s vlastným názvom a povedomím jej obyvatel'ov. V kontexte prítomnej práce je Dolná zem békešsko-čanádska a aradsko-banátska oblast'. Dolná zem je súčast'ou širšieho skúmaného priestoru južne od hranice Slovenska, vymedzeného lokalitami so slovenským osídlením.

\section{Príbeh osídlenia}

Identita slovenských obyvatel'ov z horných stolíc Uhorska bola konštruovaná na základe ich jazykovej, stavovskej, náboženskej a regionálnej príslušnosti. Až v súvislosti s národným obrodením sa začali etablovat' ako etnicky svojbytné spoločenstvá a národnostné minority. Kolonizácia Dolnej zeme bola riadený a masívny proces - dosídlenie existujúcej, založenie novej, alebo znovuzaloženie zaniknutej osady. Tento proces sa týkal viacerých v RakúskoUhorsku prítomných etník. Niektoré lokality boli kolonizované ako etnicky homogénne, v iných sa stretlo niekol'ko európskych etník, náboženstiev, jazykov, regionálnych kultúr, spoločenských vrstiev a socioprofesijných skupín. Revitalizácia územia vlastníkmi (šlachtou, král'om, armádou a cirkvou) prebiehala od prelomu 17. a 18. storočia do konca 19. storočia. V kontexte slovensky hovoriaceho obyvatel'stva prebiehala $\mathrm{v}$ troch stupňoch:

1. z územia horného Uhorska (dnešného Slovenska) na územie dnešného Mad’arska, 
2. odtial' do Báčky, Banátu, Sriemu a Bihoru (časti dnešného Chorvátska, Srbska a Rumunska),

3. odtial' na územie Bulharska. (Botík, 2007:179-181)

Nasledujúce etapy a prúdy pozostávajú nielen z pohybov obyvatel'ov územia dnešného Slovenska na juh, ale aj z kaskádovitého presunu potomkov týchto kolonistov d'alej na juh. Predstavujú ich migrácie niekedy úplne odpútané od územia Slovenska a materského národa. Ich výsledkom sú osady založené až v 20. storočí alebo d’alšie dosídl'ovanie slovenských lokalít existujúcich $\mathrm{z}$ predchádzajúcich kolonizačných vín. Ide najmä o presun obyvatel'ov z hornatých oblastí do nížinných, z prel'udnených do redšie osídlených, z chudobných do bohatších. ${ }^{4} \mathrm{Z}$ toho dôvodu sú dnešné slovenské komunity neraz diverzifikované po stránke nárečia, vedomia pôvodu, kultúrnych tradícií, náboženskej príslušnosti a pod. Dôležitými faktormi neskoršieho vývoja sú aj emigrácia (do západnej Európy, zámoria a Austrálie v 20. storočí) a repatriácia do Československa (1946 - 1948), kedy sa niektoré slovenské komunity oslabili o výraznú čast'. Ich miesto vyplnili zväčša práve Slováci z menej rozvinutých hornatých oblastí, alebo príslušníci majority, či iných minorít. Aj preto dnes v mnohých lokalitách so slovenským osídlením nachádzame pôvodom, jazykom a kultúrou pomerne heterogénne spoločenstvá, tvorené potomkami rodín, ktoré prišli priamo z územia Slovenska, aj rodín z lokalít osídlených v rámci nasledujúcich kolonizačných etáp a prúdov. Príkladom je sekundárna kolonizácia békeščabianskych a sarvašských Slovákov, ktorí v roku 1746 založili Slovenský Komlóš. Ďalší osadníci z týchto lokalít založili v roku 1754 Níred’házu (Papuček, Balážová, 2001:156). Okrem záznamov v cirkevných matrikách na jednotlivých farských úradoch to dokazujú aj priezviská, rozdielne nárečové varianty (niekedy aj $\mathrm{v}$ rámci jednej dediny), prvky tradičnej kultúry, lokálna mytológia a kolektívna pamät' obyvatel'ov.

\footnotetext{
${ }^{4}$ Papuček - Balážová pri kolonizácii územia dnešného Mad’arska slovensky hovoriacimi osadníkmi z územia Slovenska rozlišujú tri etapy: 1. 1690 - 1711 - živelné st’ahovanie poddaných z Nitrianskej, Novohradskej, Hontianskej a Abovskej stolice do oblastí ako prvých oslobodených spod osmanskej okupácie v severných častiach dnešného Mad’arska (Zadunajsko, Pilíš, mad'arská čast' Novohradu, peštianska a zemplínska oblast'). 2. 1711 - 1740 -zemepanská kolonizácia - riadený presun poddaných na oslobodené územia vlastníkov, zo slovenských oblastí západne od rieky Hron do Zadunajska a priestoru medzi Dunajom a Tisou. 3. 1740 1790 - vznik d’alších a dosídlenie existujúcich osád Slovákmi z rovnakých zdrojových oblastí (2001:155-156).

Podl’a Babiaka dosídlovanie územia dnešného Srbska (najmä autonómie Vojvodina) Slovákmi je súčast'ou všeobecnej kolonizačnej vlny, ktorá začína po roku 1740 . V prvej etape tejto vlny, do roku 1790, bol dosídlený región Báčka osadníkmi z hornouhorských žúp (Novohradská, Hontianska, Liptovská, Zvolenská, Nitrianska). V d’alšej etape, na prelome 18. a 19. storočia, Slováci z územia Slovenska aj Báčky prišli do Banátu. V nasledujúcej etape, v druhej polovici 19. storočia a na prelome 19. a 20. storočia, dosídlili Sriem (2001:109-110).

Na územie dnešného Chorvátska, osobitne Slavónie - oblasti medzi riekami Sáva a Dráva, prichádzajú prví Slováci z Oravy a Kysúc už koncom 18. storočia (Martin-Našice), masívnejšie však v druhej polovici 19. storočia (Markovec, Jelisavec, Josipovec), poslední začiatkom 20. storočia (Bartalská, 2001:89-90).

St’ahovanie Slovákov na územie Rumunska prebiehalo v 2. polovici 18. a najmä v 1. polovici 19. storočia. V prvom prúde do aradsko-banátskych oblastí prichádzajú slovenskí kolonisti z územia Mad’arska (ako sekundárna a terciálna kolonizácia). V d’alšom prúde, na prelome 18. a 19. storočia, do bihorsko-salajskej, satmársko-marmarošskej oblasti a Bukoviny prichádzajú Slováci z Gemera, Šariša, Zemplína, Oravy, Kysúc a okolia Zvolena. Určitá čast' z nich sa na prelome 19. a 20. storočia presunula do Bulharska (Štefanko, 2001:234).
}

XLinguae, Volume 11, Issue 4, October 2018, ISSN 1337-8384, eISSN 2453-711X 
Zakladanie a dosídl'ovanie dedín Slovákmi bolo v niektorých prípadoch zložitejšie, ako by sa na prvý pohl'ad mohlo zdat', čo úplne presne kopíruje a vypovedá o (nielen etnickej) genéze celého európskeho priestoru. Navyše, súčasný stav, kultúru a identitu týchto komunít v čoraz väčšej miere vysvetl'uje nie príchod prvých Slovákov (o ktorých je najčastejšie reč), ale následné, neraz obojsmerné, migrácie l’udí a difúzie kultúr. Tak začalo, niekde až tristoročné spolužitie slovenských prist'ahovalcov a ich potomkov $\mathrm{s}$ novými susedmi, vodlišných, nezriedka dovtedy nepoznaných podmienkach.

\section{Identita}

Identita v najširšom filozofickom význame znamená zhodnost', totožnost', vlastnost' toho, čo je identické/zhodné i ked' aj rozličným spôsobom vnímané alebo nazývané. Zo psychologického hl'adiska získaním identity sa jednotlivec radí k danému typu entity, s ktorou samou alebo s jej vlastnost’ami sa stotožňuje, alebo sa cíti byt' jej súčast'ou. Identita je výsledkom identifikácie - procesu stvárňovania seba samého podl'a vzoru iného. Jednotlivec si osvojuje vlastnosti iného človeka/skupiny a vykazuje podobné správanie. (Krech, Cretchfield, Ballachey, 1968:151) Fay popiera substanciálne Ja iba ako atomisticky chápanú elementárnu, zapúzdrenú entitu. Identifikácia je proces interaktívny a sociálny. Pozostáva z autoidentifikácie (uvedomenia si vyčlenenia od rozdielneho) a vyčleňovania inými. (Fay, 2004:64) V sociálnom jestvovaní prostredníctvom spoločnej kultúry sa vytvára identita ako jeden $\mathrm{z}$ výsledkov tohto procesu. $\mathrm{V}$ osobe/skupine nie je nič, čo by jej identitu dopredu predurčovalo zvnútra. Nemá naprogramovaný svoj obsah, naopak, je maximálne otvorená a flexibilná voči svojmu prostrediu a významom, platným v prostredí svojej existencie. (Bačová, 2017) Socio-psychologická teória vychádza z faktu, že mysel' a osobnost' nie sú súčast'ou l'udskej výbavy, ale konštruujú sa počas života pôsobením sociokultúrneho procesu. Zo sociálno-psychologického hl'adiska, ktoré je $\mathrm{v}$ prípade výskumu komunít a malých spoločenstiev existujúcich ako primárne skupiny najefektívnejším nástrojom, je identita „,o, čo môžeš povedat', že si. To, čo si, si vytváraš na základe toho, že ti povedia, že týmto môžeš byt" (Bačová, 2017 podl'a Johnstone, 1973) Brubaker a Cooper definujú 5 najčastejších použití identity: 1. ako základ sociálneho a politického konania v protiklade $\mathrm{k}$ záujmu (Ja verzus univerzálny záujem); 2. ako kolektívny jav fundamentálnej rovnakosti členov skupiny; 3. ako jadro koncepcie Ja (individuálneho aj kolektívneho); 4. ako produkt sociálneho a politického konania (procesuálnost' a interaktívnost' identity); 5. ako produkt konkurujúcich diskurzov. Autori zdôrazňujú protikladnost' použití 2. a 3 . (založených na rovnakosti) oproti 1., 4. a 5. (ktoré rovnakost' odmietajú). (Findor, 2005:46-47 podl'a Brubaker, Cooper, 2000:6-8)

Človek disponuje takým počtom identít, kol'kých skupín je/cíti sa byt' členom. Podl'a symbolického interakcionizmu sú identity hierarchicky usporiadané. Komplexná, v podstate abstraktná a nepomenovatel'ná identita (Identita) je zložená z množstva parciálnych konkrétnych identít (podl'a členstiev v skupinách). V konkrétnom procese identifikácie sa preto neprejavujú vždy všetky identity, ale len niektoré alebo jedna. Preto sa Identita môže javit’ ako nejednoznačná, premenlivá, mnohofarebná a viacvýznamová. Záleží od konkrétnej identifikačnej situácie, ako sa v nej potrebuje/má človek/skupina identifikovat'. (Lenovský, 2005) Evidentným 
príkladom je etnická identifikácia príslušníkov slovenských komunít v skúmanom priestore, ktorí sa ako Slováci identifikujú príslušnými spôsobmi (symbolmi) v príslušných situáciách. V iných situáciách sa identifikujú inými symbolmi a inými identitami. Slovák, slovensky hovoriaci, muž, matka, krstní rodičia, katolík, gazda, Nadlačan, občan Srbska, dolnozemec - to všetko sú identity. Nie sú prvoplánovou účelovou nálepkou jednotlivca bez pozadia, ale kumulujú, selektujú a prelínajú sa od jeho narodenia až do smrti. Niektoré identity existujú len počas istých etáp života - sú ovplyvnené vekom, stavom, zamestnaním či aktuálnym bydliskom. Iné, naopak, môžu pretrvávat' po celý život (napríklad lokálna, občianska, rodová, pohlavná identita), alebo aj po generácie (napríklad jazyková, etnická, náboženská, niekedy aj socioprofesijná identita). Identita neraz zostáva dôležitá aj po smrti, pre tých ostatných - stáva sa súčast'ou kultúrneho dedičstva a pilierom identity celej society (napríklad v podobe odkazu, myšlienok a diela elít/významných osobností).

$\mathrm{Aj}$ predmetné slovenské komunity dokazujú, že l'udia, ktorí sú rovnakí/podobní etnicky, môžu z toho dôvodu byt' rovnakí/podobní aj inak, napríklad kultúrne, jazykovo, socioprofesijne, nábožensky. Vytváranie skupín na etnickom princípe môže v minoritnom prostredí jednotlivcom poskytnút' efektívnejšie napíňanie svojich ciel'ov prostredníctvom politického, spolkového, spoločenského a kultúrneho života. Niekedy, napríklad v etnicky homogénnom prostredí, iná reálna možnost' ani nie je.

Každá sociálna identita - príslušnost' ku skupine, je formovaná a podmienená zdiel’aním jazyka, hodnôt, noriem, ideí a postojov (kultúry) tejto skupiny. Jedným z najsignifikantnejších socioidentifikačných prostriedkov je jazyk. Ako symbolický systém, komunikačný nástroj, čast' kultúry a médium ešte väčšej časti kultúry, je jazyk v každej skupine jedinečný. Každá skupina na základe vlastných špecifík, ktoré ju odlišujú od ostatných skupín, používa svoj vlastný jazyk. Jazyková odlišnost' tu, samozrejme, spočíva aj v nárečiach, slangu, intonácii, výslovnosti, frázach, alebo aj v takmer nepostrehnutel'ných jazykových nuansách, známych len najbližšiemu okruhu vlastných a „tých“ druhých. Ak ide o skupinu/spoločenstvo založené na etnickom princípe, vyjadrenie príslušnosti k nemu (etnická identita) je podmienené zdiel'aním etnických znakov (etnokultúry). Jazyk je, zdalo by sa, jej neoddelitel'nou súčast'ou a nenahraditel'nou zložkou. No tak, ako rozmanitá je etnicita (etnické cítenie) a kultúra (spôsob života a myslenia), a ako zložito je stratifikovaná identita, vrátane tej etnickej, $\mathrm{v}$ minoritných spoločenstvách je mnohotvárna podoba jazyka, jeho používanie, vzt’ah a príslušnost' k nemu (jazyková identita). Jazyková asimilácia, bilingvizmus, alebo (medzigeneračná) jazyková kontinuita predstavujú tie najzretel'nejšie a najzjednodušenejšie výsledky etnojazykových procesov v minoritnom prostredí. Niekde je jazyk podstatný a jazyková identita členstvo $\mathrm{v}$ etnickej komunite podmieňuje, inde členstvo v nej nepodmieňuje, lebo už zanikol, a integračnú a socializačnú funkciu jazykovej identity prevzali iné identity, napríklad kultúrna, lokálna, či generačná.

\section{Enkláva, diaspora a jazykový ostrov}

Pri výskume etnických minorít je vymedzenie minority a definovanie jej členov nevyhnutné. U Slovákov v Srbsku, Rumunsku, čiastočne i Chorvátsku je 
možné uvažovat' v intenciách enkláv a diaspor. Otázka pôvodu a jazyka je tu kl'účová, lebo ovládanie a používanie slovenčiny, spolu so slovenským pôvodom a deklarovaním etnickej identity je pomerne jednoznačné. Nie vždy a všade je evidentné, či ide o enklávu alebo diasporu. Potvrdzujú to princípy jestvovania väčšiny komunít v Mad'arsku, ktoré sú označované za slovenské. To, čo definuje etnickú enklávu (kultúrna kontinuita, medzigeneračná transmisia, reprodukcia kultúry, jazyka, etnickej identity a pod.), v týchto komunitách už nie je prítomné ako celok. A to, čo definuje etnickú diasporu, ešte nie je úplne najkomplexnejšou charakteristikou spôsobu existencie týchto l'udí. Pôvodne okrem prevládajúceho agrárneho spôsobu života bola d'alšou podstatnou črtou etnogenézy skúmaných Slovákov v celom priestore južne od hranice Slovenska etnoteritorialita - zoskupovanie sa do etnicky homogénnych územných a sídelných útvarov (regióny, dediny, časti, ulice). (Botík, 2007:179) Výsledkom bol vznik etnických enkláv. V Mad'arsku, ale aj v prevažnej časti Chorvátska pôsobením asimilačných faktorov počas nasledujúcich generácií takéto slovenské komunity zanikli. Ak by súčasné jestvovanie ich potomkov (rodín a jednotlivcov) bolo charakteristické životom mimo vlastného etnického spoločenstva, „roztrúsenost'ou“ v malých počtoch v majoritnom obklúčení, prerušenou jazykovou, kultúrnou kontinuitou, išlo by o diaspory. Ich minoritnú existenciu v súčasnosti udržiava nielen inštitucionálna sféra (ako národnostnú), ale ešte stále aj komunitná (ako lokálnu). Slovenský genius loci skúmaných lokalít ešte nie je len historickým a ako kultúrne dedičstvo zaznamenaným javom, ale stále fenoménom, ktorý udržiavajú živí l'udia. I ked' sú to najmä príslušníci najstaršej generácie, z ktorých za Slovákov sa už skoro nikto nepovažuje.

Aj z týchto dôvodov sa ako lepšia optika ponúka teória jazykových ostrovov. Umožňuje uchopit' komunity, ktorých členovia sa už etnicky jasne neidentifikujú ako minorita, v komunikácii nepoužívajú slovenský jazyk, ale etnokultúrne prvky a jazykové stopy sú ešte stále prítomné (napríklad znalost' slovenského jazyka u najstaršej, miestami aj strednej generácie). Slovenské obyvatel'stvo v skúmanom území pochádza z rôznych oblastí severného Uhorska. Vo svojom pôvodnom prostredí hovorilo značne odlišnými nárečiami a popri nepochybne spoločných kultúrnych črtách si prinieslo aj špecifickú kultúru nesúcu regionálne znaky. Tieto jazykové a kultúrne odlišnosti sa zachovali dodnes a práve prostredníctvom nich vzniká etnická identita a etnicita súčasných komunít. Navyše, ich jazykové a kultúrne znaky vo vel'kej miere determinovalo ich náboženstvo (katolicizmus/protestantizmus). (Divičanová 1999:30-31) Ak sa obyvatelia slovenského pôvodu v Mad’arsku seriózne zamýšlajú nad tým, či sú Slováci alebo Mad'ari a čo to vlastne znamená, sami dobre vedia, že sú iného pôvodu ako mad'arskí Mad'ari. Svoju etnicitu (ako etnické cítenie) logicky obracajú bud' k vlasti (Mad'arsku), ale aj/alebo k etnickému pôvodu. Ten definujú podl'a jazyka predkov (akým jazykom rozprávali ich rodičia a starí rodičia). Čo prevládne, to rozhoduje pri autoidentifikácii, no na skutočnosti to nič nemení. Videnie slovenských komunít $\mathrm{v}$ Mad'arsku nie ako Slovákov či obyvatel’ov slovenského pôvodu, ale ako slovenských jazykových ostrovov oslobodzuje týchto l'udí (aj bádatel'ov) od povinnosti etnicky sa identifikovat', lebo mnohí z nich toho ani pri najlepšej vôli nie sú schopní. Jazykové ostrovy sú mimoriadne efektívnym metodologickým východiskom, lebo odhalujú 
nielen jazyk a etnogenézu, ale aj všetky podstatné etnické, kultúrne, náboženské a priestorové charakteristiky.

Pojem jazykový ostrov úzko korešponduje s pojmom lokálna identita (príslušnost' $\mathrm{k}$ lokalite a lokálnej societe). Vypovedá nielen o mieste narodenia, bydlisku, pobyte, ale aj o najrozmanitejších charakteristikách lokality a lokálnej society (vo forme faktov, alebo stereotypov a mýtov). Nadlačan - obyvatel' mesta Nadlak, znamená aj Slovák, evanjelik, pol’nohospodár, realizujúci kultúrne tradície slovenskej proveniencie, aktívne používajúci nadlacký variant slovenčiny atd'. A to aj napriek tomu, že pre Nadlak je už dávno typická multietnickost', multikonfesionálnost', socioprofesijná stratifikácia (nerolnnícke zamestnania, emigrácia za prácou), kultúrna homogenizácia a deetnizácia miestnych obyčají životného a kalendárneho cyklu. V Nadlaku žijú aj takí Nadlačania, ktorí nezodpovedajú ani jednej zaužívanej charakteristike okrem lokálnej príslušnosti, dokonca ich je väčšina.

Pojem jazykový ostrov je determinovaný aj pojmom kultúrna identita príslušnost' ku kultúre. Kultúrna identita sa z vel'kej miery formuje prostredníctvom kultúrneho dedičstva. „, $V$ dejinách dolnozemských Slovákov kultúra a umenie patria $k$ najsilnejším oporám národnej identity. ...popri náboženskom a cirkevnom živote, školstve a pestovani zvykov a tradícií, jednotlivé formy umenia boli a sú emblémami, ale aj výstavnými skriňami národného života dolnozemských Slovákov. " (Babiak, 2016:180) Kultúrne dedičstvo komunít potomkov Slovákov obsahuje množstvo prvkov slovenskej proveniencie. Pri úprimnej a serióznej snahe zachovat' ho, aj ked' primárne nie ako slovenské, ale ako lokálne, regionálne, či dedičstvo predkov, sa etnickým znakom nedá vyhnút'. Nie je zriedkavé, ked' aj v takmer asimilovaných komunitách svoje dedičstvo zachovávajú a využívajú pomad’arčené, alebo deetnizované a lokalizované. Slovenský jazyk ako živý zanikol, ale ostatné tradície ostávajú.

Azda najreprezentatívnejším príkladom vzt'ahu jazykovej a etnickej identity v prostredí európskych minorít je príbeh Békešskej Čaby. V roku 1718 bola slovenskými kolonistami z Novohradskej, Gemerskej a Hontianskej župy (Gomboš, 2005:18) znovu obnovená osada Békešská Čaba, kde v tom čase žilo 22 katolíckych rodín a staval sa malý kostol. V roku 1784 tu už žilo približne 10.000 Slovákov (slovensky hovoriacich Čabanov) a o 50 rokov neskôr 21.757. V roku 1857 sa z 26.705 Békeščabanov za Slovákov hlásilo 20.671 (77,2\%). Čaba bola najväčšou dedinou Európy (lebo nemala štatút mesta) a najpočetnejším sídlom slovensky hovoriaceho obyvatel'stva. Ani vo vtedy najväčších mestách na území Slovenska nežilo viac Slovákov. V roku 1900 v Čabe žilo 37.547 obyvatel'ov. ${ }^{5}$ Oficiálny štatút mesta získala v roku 1919 v rámci nového štátu - Mad'arska. Pri sčítaní obyvatel'stva v roku 1920, i napriek vrcholiacej mad’arizácii a manipuláciám štatistík, boli Slováci s počtom $24.710(52,98 \%)$ ešte stále $v$ meste väčšinou. Za evanjelikov a. v. sa vtedy hlásilo 29.725 obyvatel’ov $(63,79 \%)$, čo vzhl'adom na to, že miestnymi evanjelikmi

\footnotetext{
${ }^{5}$ Vtedy ju v počte Slovákov prekonalo hlavné mesto Budapešt', kde ich žilo 37.837. Zaujímavý je nárast počtu slovenského obyvatel'stva $\mathrm{v}$ Budapešti, kde $\mathrm{v}$ roku 1869 úrady evidovali len 12300 Slovákov a v roku 1900 už takmer 38.000. Neoficiálne odhady hovoria o $60.000-80.000$ Slovákoch, ktorí isté obdobie žili a pracovali v Budapešti. (Kováčová 2014:15)
}

XLinguae, Volume 11, Issue 4, October 2018, ISSN 1337-8384, eISSN 2453-711X 
boli takmer výlučne Slováci, upravuje aj ich skutočné etnické zastúpenie. ${ }^{6}$ (Borgul’a, Švihran 1979, Jančovic, 2017) Počas výmeny obyvatel'stva v rokoch 1946 - 1948 sa z Békešskej Čaby do Československa odst’ahovalo 7.408 Slovákov (Šutaj, 2005), čo vzhl'adom na počet tých, čo stali, nebolo vel'a.

O pol storočia neskôr už bola etnická a jazyková situácia v meste úplne iná: podl'a cenzu v roku v roku 2001 sa z 67.968 obyvatel'ov mesta za Slovákov hlásilo 1.687, silnú väzbu k slovenskej kultúre deklarovalo 2.688 a používanie slovenčiny uviedlo 1.233 obyvatel'ov. V roku 2011 sa z 62.050 Čabanov za Slovákov hlásilo 1.881, materinský jazyk deklarovalo 665 , používanie slovenčiny $\mathrm{v}$ rodinnom a priatel'skom kruhu 1.133. Na základe toho bola slovenská príslušnost' pripísaná 2.513 Čabanom. (Elements of nationalit y affiliation of the population, 2011Békéscsaba, 2017) V roku 2015 sa z približne 60.000 obyvatel'ov mesta 93,8 \% hlásilo za Mad'arov, 5,9 \% za Slovákov, 0,6 \% za Nemcov, 0,4 \% za Rumunov a 0,4 \% za Rómov. (Jančovic, 2017) V priebehu troch storočí sa z jednej osmanskou okupáciou zdevastovanej a vyl’udnenej uhorskej osady počas prvej polovice jej novej existencie stala takmer 40-tisícová slovenská dedina a počas polovice druhej mad’arské vyše 60-tisícové župné mesto s oficiálnym 5,9\% zastúpením Slovákov. Pritom neišlo o výmenu obyvatel'stva za iné. Békešská Čaba je dnes svetoznáma svojou klobásou a klobásovým festivalom, ktoré sa stali hungarikom a o ich slovenskej proveniencii takmer nikde nie je ani zmienka.

Tlak obklopujúcej majority, politika štátu aj snaha miestnych byt' čo najlojálnejšími a najlepšími občanmi svojej vlasti ich nútili/motivovali zamenit’ svoj minoritný status za majoritný. Minoritná identita bola prekážkou plnohodnotného života a využívania existujúcich možností profitu $\mathrm{v}$ majoritnej spoločnosti. Pomad'arčenie, vrátane mena a priezviska, bolo podmienkou získania dobrého zamestnania, napríklad v štátnej správe, no aj vzdelania a spoločenského uznania. Deti boli za používanie slovenčiny v školách (aj mimo výučby), i na ulici trestané, slovenskí učitelia a kňazi boli nahrádzaní mad’arskými a pod. Jedným z najvýznamnejších nástrojov tejto premeny bola výmena materinského jazyka. Realizovala sa elimináciou príležitostí používania slovenského jazyka pod vplyvom jeho negatívneho heteroobrazu v majoritnej spoločnosti, čo vyústilo do jeho nahrádzania mad'arčinou nielen vo sfére spoločenského, verejného, náboženského, politického, profesijného života a vzdelávania, ale aj $\mathrm{v}$ komunitnom a rodinnom živote. Ked’že túto úroveň „neovládal“ štát ani majorita, možno konštatovat', že zmena etnickej identity a výmena materinského jazyka bola rozhodnutím samotných príslušníkov minorít. Navyše, slovenčina tu stratila úplne všetky funkcie. Za najvyšší spoločenský princíp v Mad’arsku sa permanentne považuje (aj vyžaduje) štátna príslušnost'. S tým sa stotožňuje nielen majorita, ale i prevažná čast' potomkov Slovákov v Mad'arsku. Príbeh Slovákov v Békešskej Čabe dokazuje, že schopnost' jednotlivcov aj najpočetnejších etnických spoločenstiev menit’ tie svoje identity, o

\footnotetext{
${ }^{6}$ Hlásenie sa Slovákov k mad'arskej národnosti alebo jazyku bolo v Mad’arsku bežné, ked’že sa často považovali etnicky za Slovákov, ale svoju národnú príslušnost' chápali politicky. O generačnej mad'arizácii svedčí aj to, že kým v roku 1890 žilo na území súčasného Mad'arska 213.000 Slovákov, v roku 1910 to bolo len približne 163.000, pričom napríklad početnost' Slovákov vo vojvodinských stoliciach v tom čase rástla. (Filadelfi 2012)
} 
ktorých sa zväčša hovorí s pátosom, považujú sa za primordiálne a nezmenitel'né jadrá a piliere, dedičstvo predkov, je niekedy ovel'a väčšia, ako by sa predpokladalo.

V Chorvátsku je situácia s postavením slovenského jazyka v slovenských komunitách podobná ako v Mad'arsku ale z úplne iných dôvodov. Jazyková a etnická asimilácia Slovákov v Chorvátsku je spôsobená zhodnou náboženskou identitou katolíckej časti slovenskej minority s chorvátskou majoritou. Podobnost' jazykov si nevynútila potrebu vlastných kňazov. Navyše, pretrvávanie náboženskej endogamie ako prevládajúceho princípu výberu manželského partnera do polovice 20 . storočia podporilo uzatváranie katolíckych, i ked' slovensko-chorvátskych manželstiev, kde slovenčina sa postupne zo života vytratila. Jazyk a identita pretrvali viac v prostredí evanjelickej časti chorvátskych Slovákov, ktorí ak si nemohli nájst' manželského partnera vo vlastnej skupine, našli si ho v slovenskom evanjelickom prostredí Vojvodiny. V súčasnosti však z dôvodu jazykovej podobnosti a straty funkcií slovenčiny $\mathrm{v}$ reálnom živote najmä $\mathrm{v}$ prostredí generácie detí a mládeže dochádza k jazykovej a etnickej asimilácii. Príkladom je dedina Sol’any osídlená katolíckymi a evanjelickými Slovákmi aj Chorvátmi. Fungujú tu dva folklórne súbory. V tom slovenskom členovia tancujú slovenské l’udové tance a spievajú slovenské l'udové piesne. Počas prestávok komunikujú v slovenčine, chorváčtine, alebo naraz $\mathrm{v}$ obidvoch jazykoch. V tom chorvátskom sa odohráva to isté, $\mathrm{v}$,chorvátskom variante“. Niektorí členovia navštevujú obidva miestne folklórne súbory, ovládajú obidva jazyky. Ide prevažne o deti a mládež zo zmiešaných rodín. Dôvodom výberu súboru nie je výhradne etnická príslušnost', ale kamarátska skupina a osobná preferencia (podl'a repertoáru, kvality súboru, ktorý sa im viac páči). Pri detoch a mládeži zo zmiešaných manželstiev etnický princíp ani nie je možné uplatňovat', lebo mnohí sa jasne etnicky identifikovat' nedokážu/nechcú/nevidia na to relevantný dôvod. Faktom je, že potomkovia slovenských katolíkov sa tu dnes hlásia za Slovákov v ovel’a menšej miere ako tých evanjelických i napriek tomu, že tiež ovládajú slovenský jazyk a majú slovenský pôvod. Za Slovákov tu všetci považujú tých evanjelických Sol'ančanov, lebo tí majú vlastné/odlišné vierovyznanie, ktoré sa permanentne realizuje v slovenskom jazyku.

V srbskej enkláve Vojlovica, dnes časti mesta Pančevo, je dodnes najreprezentatívnejšou lokálnou, etnickou a kultúrnou tradíciou chodenie s betlehemom. Vzt'ahuje sa na miestnych Slovákov, aj ked' súčast'ou lokálnej komunity sú dlhodobo aj Mad’ari, Rómovia, Rumuni, Macedónci, Srbi a ostatné etniká bývalej Juhoslávie. Betlehemská obchôdzka je súčast'ou obyčají vianočného cyklu. Na Štedrý deň (24. 12.) začína večer po službách Božích. Slovenskí mládenci v príslušných kostýmoch a maskách zorganizovaní do skupiny betlehemcov ${ }^{7}$ navštevujú všetky slovenské domácnosti (cca 50 - 70), kde zahrajú betlehemskú hru (6 - 10 minút). Pochôdzka trvá zvyčajne do 7:00 nasledujúceho rána. Niekedy sú skupiny betlehemcov dve, podl'a početnosti generácie mládencov. Ak ich pozvú aj miestne srbské a mad’arské domácnosti, čo sa stáva zriedkavo, patrí sa navštívit' ich

\footnotetext{
${ }^{7} \mathrm{Na}$ čele skupiny je hviezdar, d’alej dvaja anjeli, traja králi a niekol'kí čobani (pastieri). Počet postáv je od 8 do 12 . Za betlehemcov idú mládenci vo veku $12-15$ rokov. V skupine sú približne do veku 20 - 25 rokov, resp. kým sa neoženia. V minulosti zvykli s betlehemom chodit' v ojedinelých prípadoch aj ženatí, podobne ako dnes starí mládenci.
}

XLinguae, Volume 11, Issue 4, October 2018, ISSN 1337-8384, eISSN 2453-711X 
a zahrat' hru. Pozvaní sú najmä vtedy, ak z takejto rodiny majú mládenca v skupine betlehemcov. Pre mnohých slovenských mládencov je členstvo v betleheme jediná slovenská obyčaj, ktorú dodnes pravidelne realizujú. V niektorých prípadoch členmi skupiny bývali aj miestni nemeckí, dodnes mad'arskí či srbskí mládenci. Dôvodom je možnost' zarobit' si ${ }^{8}$, podmienkou priatel'stvo. Znalost' slovenského jazyka nie je nevyhnutná, lebo nie všetky postavy v hre rozprávajú.

Z pohl'adu interetnických a interkonfesionálnych vzt'ahov vo Vojlovici je zaujímavé, že slovenskí mládenci sú výhradne evanjelici a. v., mad'arskí sú reformovaní (kalvíni), srbskí sú pravoslávni, pričom betlehemská obchôdzka sa v skúmanom priestore v slovenskom evanjelickom, ani kalvínskom, ani pravoslávnom prostredí nikde nevyskytuje. Viaže sa výlučne na katolicizmus. Rovnako je tomu aj v rumunskej bihorsko-salajskej oblasti so slovenským katolíckym osídlením, kde sa betlehemské obchôdzky mládencov ešte realizujú tiež a kde sú členmi skupín nezriedka rumunskí priatelia. A to i napriek tomu, že sú pravoslávneho vierovyznania a túto tradíciu nemajú. Túto tradíciu priniesli a realizujú aj katolícky Slováci z Bihoru, ktorí sa presídlili do nížinných evanjelickými Slovákmi obývaných lokalít (napr. mesto Nadlak, dedina Butín). Na tradovaní etnických prvkov jednej minority sa tak zúčastňujú príslušníci iných minorít, alebo majority. Všetci zúčastnení to považujú za prirodzený proces, lebo organizačným princípom pre ich nie je jazyková či etnická identita, ale lokálna a sociálna identita.

\section{Revitalizácia jazyka, identity a kultúry}

Výsledkom aktuálnych demografických, asimilačných a globalizačných trendov je vyl’udňovanie lokálnych komunít. To eliminuje perspektívy nielen rozvoja, ale aj pretrvania minorít. Alarmujúca situácia z pohl'adu zachovávania slovenského jazyka, reprodukcie minoritnej kultúry a etnickej identity v skúmaných slovenských komunitách je faktom. V Mad'arsku a Chorvátsku je tento stav spôsobený predovšetkým asimiláciou predchádzajúcich generácií, čiastočne aj odchodom mládeže a mladých rodín v produktívnom veku do miest (najmä v Mad’arsku), alebo z Chorvátska do zahraničia. V Srbsku a Rumunsku vždy boli, aj sú asimilačné tlaky ovel’a menšie, ale situácia je podobná, spôsobená odchodmi do miest, zahraničia, najmä na Slovensko. Návratnost' tých, ktorí odchádzajú, je malá.

I napriek tomu, zaujímavým je aj čoraz menej ojedinelý proces, kedy sa už asimilovaní potomkovia učia jazyk svojich predkov, zaujímajú sa a obnovujú už zaniknuté kultúrne tradície, organizujú nové podujatia, zakladajú minoritné inštitúcie a organizácie. Vedomie spoločného pôvodu a informácie o spoločnej, od ostatných odlišnej histórii a kultúre stimulujú ich spolupatričnost', vytvárajú pocit výnimočnosti. Proces revitalizácie minorít je podmienený vysokým stupňom jazykovej, etnickej aj kultúrnej asimilácie. V situácii, ked' z jazyka a tradící́ zostalo len torzo, a stopy vo vlastnom sociokultúrnom priestore sú prítomné len v prostredí najstaršej generácie, alebo už len v jej kolektívnej pamäti, sa tieto stopy stávajú exkluzívnymi. Č́m menej ich je, tým hodnotnejšími sú. Z každodennej a samozrejmej záležitosti sa stáva

\footnotetext{
${ }^{8} \mathrm{~V}$ každom dome dostávajú flašu vína a 500 - 1000 dinárov (približne 5 - 10 eur). Peniaze zbiera posledný - hviezdar. Ráno si ich rozdelia zauživaným spôsobom - na cirkevné účely venujú od 3000 (cca 30 eur) do 10000 dinárov (cca 90 eur). Darovanú sumu vždy vyhlási farár na bohoslužbách 25., alebo 26. 12. Ostatné peniaze si betlehemci rozdelia rovnakým dielom.
} 
hodnota až vtedy, ked' sa vytratí každodennost' a samozrejmost'. (Ambrózy, Králik, Martin, 2017, Kondrla, Králik, 2016, Kondrla, Pavlíková, 2016)

Napríklad v Mad’arsku dnes pôsobí takmer 100 oficiálnych slovenských národnostných inštitúcií a organizácií. (Spolky a organizácie 2017) Slováci tu majú založených 116 miestnych menšinových samospráv, viac majú len Rómovia (999) a Nemci (377). (Kokaisl a kol., 2014:125) Slovenčinu sa učí (alebo sa s ňou dostáva do kontaktu) približne 6.300 detí v 46 základných a 72 materských školách. V Mad’arsku sú dve slovenské národnostné gymnáziá - v Budapešti a v Békéšskej Čabe. Slovenčina ako cudzí jazyk sa vyučuje aj na strednej škole v Novom Meste pod Šiatrom a v Balašských Ďarmotách a v štyroch vysokoškolských inštitúciách. V každej z nich prebieha vysokoškolská príprava pedagógov a humanitne zameranej inteligencie. (Tri typy slovenských národnostných škôl v Mad’arsku, 2015) Ciel’om národnostnej politiky, vzdelávania a kultúry Slovákov v Mad’arsku istotne nie je výchova nových Slovákov a slovenských „nejtiv spíkrov“ z mad’arských detí a mládeže slovenského pôvodu. Rovnako nemožno hovorit' o masovosti. Ale nespochybnitel'ná a legitímna je ambícia vytvorenia podmienok na budovanie vzt'ahu mladých l'udí k jazyku a kultúre svojich najbližších predkov, poskytnutie špecifického kapitálu na zvýšenie ich konkurencieschopnosti.

Podobné snahy sú evidentné aj v Chorvátsku, i ked' tam vzhl'adom na rádovo menší l'udský potenciál, sú podmienky, možnosti, aj adresáti prítomní v ovel'a menšej miere. V Rumunsku a Srbsku možno očakávat' rovnaké revitalizačné potreby približne o dve, tri desat'ročia, lebo generácia súčasných detí a mládeže je práve „na pomedzi“" medzi dvoma jazykovými svetmi.

Vynikajúcim príkladom mobilizácie jednotlivcov, vytvárania komunity a minoritnej identity sú v úvode spomínaní potomkovia Huncokárov. Jazyk Huncokárov je v komunite ich potomkov nepoužívaný od druhej svetovej vojny a nachádza sa vo fáze "kriticky ohrozený". Poslední traja používatelia, ktorí aktívne komunikujú, sú seniori narodení v roku 1930 a skôr (survivals). Ďalší, pamätníci (remembers), ktorých je približne 50, majú vel'mi limitované znalosti (frázy, piesne, kratšie žánre).

Latentní noví hovoriaci (latent new speakers) sú najmladšia generácia potomkov, ktorí jazyk neovládajú, no majú oň záujem. Je ich 150. Zaujímavá je skupina záujemcov a sympatizantov "zvonka”, ktorá nie spätá s etnickým pôvodom a identitou, ale s regionálnou príslušnost'ou, citovými väzbami, osobnými zál'ubami, či náklonnost'ou. (Šatava, 2017:324)

Pozornost' o problematiku revitalizácie je výsledkom zvýšeného vedeckého záujmu o jazykovú asimiláciu a zánik viacerých jazykov (Krauss, 1992; Brenzinger, 2007; Austin-Sallabank, 2011 a iní). Aplikovaný rozmer jazykovej revitalizácie predstavuje Joshua Fishmann (1991) so svojím dôrazom na zastavenie, resp. spomalenie etnojazykovej asimilácie. U mnohých etník sa to aj podarilo. (Šatava, 2017:323 a n.). Druhým aspektom je záujem potomkov samotných a spoločenská požiadavka po pomoci s revitalizáciou. Snom mnohých potomkov Huncokárov je osadenie tabúl' s názvami osád a obcí, kde ich predkovia žili a pracovali, informačných tabúl' na architektonicky a turisticky atraktívnych miestach spojených s Huncokármi, samozrejme, aj $\mathrm{v}$ huncokárčine, vybudovanie náučných chodníkov;

XLinguae, Volume 11, Issue 4, October 2018, ISSN 1337-8384, eISSN 2453-711X 
inscenovanie divadelných a hudobných predstavení v huncokárčine. (Slobodová Nováková, 2014:97-108) Dôvodom tohto záujmu je snaha zabránit' zanikaniu malých, regionálnych a menšinových jazykov, okolo ktorých sa vytvárajú komunity a identity aj potom, ked' prestali byt' jazykom bežnej komunikácie. To sa dosahuje pomocou divadla, hudby a folklóru, prekladov, večerných jazykových kurzov a pod. (Reershemius, 2009:131). Podl'a Šatavu v súčasnosti možno pozorovat' posuny v chápaní jazyka od „etnického aspektu“ (jazyk ako znak, majetok určitého etnika) k uvol'nenejšiemu konceptu, jazyku otvorenému všetkým adeptom, bez ohl'adu na ich etnický pôvod či autoidentifikáciu. (Šatava, 2017:325)

Vedomostná a vedecko-výskumná báza o slovenských komunitách, ich jazyku a kultúre, je neporovnatel'ne väčšia oproti investigatívnej (až etnoarcheologickej) práci s vel’mi náročnou kumuláciou poznatkov o jazyku Huncokárov. (Napríklad Fedičova dialektologická analýza huncokárčiny, 2014:109119.) Odhliadnuc od vedeckého výskumu, vo fáze zániku jazyka, kultúry a minoritnej identity akéhokol’vek predtým aj početného spoločenstva, sú systémové revitalizačné stratégie mimoriadne dôležité a nenahraditel'né bez ohl'adu na to, na aké spoločenstvo sú aplikované. (Ivanischeva 2016)

\section{Záver}

Európa je sociokultúrnym priestorom so špecificky organizovanou dynamikou. Táto dynamika je historicky založená na etnicite, ako kolektívnej forme spolupatričnosti. Na rozdiel od Afriky, či Blízkeho východu, kde ako primárny organizačný princíp dodnes prevláda kmeňový a náboženský nacionalizmus, alebo štátov Severnej Ameriky, ktorých spoločnost' je organizovaná na občianskom (deetnizovanom a dekonfesionalizovanom) nacionalizme, je európska spoločnost' ešte stále definovaná pôvodne etnickým nacionalizmom, ktorý sa rozvinul do národného (ako štátotvorného) občianskeho nacionalizmu, spolu s etablovaním etnických minorít. To je skutočným dôvodom, prečo nie je možné zjednodušene a globálne aplikovat', možno niekde inde úspešné, interkultúrne, interetnické a interkonfesionálne stratégie naprieč touto systémovou rozmanitost'ou. Z výskumu je evidentné, že relatívne bezproblémová koexistencia etnicky, nábožensky a kultúrne odlišných skupín so zachovaním ich kultúry a identity je v Európe možná. Dokonca je špecifickou črtou Európy a európskeho myslenia, ako je zrejmé na základe niektorých príkladov v prítomnej práci. Nevyhnutnost'ou je však použitie príslušných stratégií, dodržanie postupov a rešpektovanie systémovosti týchto procesov. Rovnako evidentné je, že v prípade použitia iných postupov je možné vel'mi úspešne etnicky, nábožensky a kultúrne homogenizovat' na prvý pohl'ad nezlučitel'né etnické kolektivity, čoho dôkazom sú iné príklady a „príbehy“ prítomné v tejto práci. A pritom ide o jednu a tú istú Európu.

The article was published with the support of Slovak Research and Development Agency under the contract No. APVV 15-0360; Scientific Educational Grant Agency under the contract No. VEGA 1/0383/18; Culture Educational Grant Agency under the contract No. KEGA 037UMB-4/2018. 


\section{Bibliographic references}

AUSTIN, P. L. - SALLABANK, J. (eds.) 2011. The Cambridge Handbook of Endangered Launguages. Cambridge: Cambridge University Press.

BABIAK, M. 2016. Tradicia a identita. Nadlac: Ivan Krasko.

BABIAK, M. 2001. Juhoslavia. In Sprievodca slovenskym zahranicim. BARTALSKA, L. (ed.), Bratislava: Dom zahranicnych Slovakov, pp. 107-132.

BACOVA, V. 2017. Problem identity v socialnej psychologii. Available online: http//:www.kvsbk.sav.sk/10rokov/bacova.htm, (21.11. 2017).

BARTALSKA, L. 2001. Chorvatsko. In Sprievodca slovenskym zahranicim. BARTALSKA, L. (ed.), Bratislava: Dom zahranicnych Slovakov, pp. 87-100.

BORGULA, M. - SVIHRAN, L. 1979. Tu sa usadime: Slováci v čabianskej oblasti. Bratislava: Tatran.

BOTIK, J. 2007. Etnicka historia Slovenska. Bratislava: LUC.

BOTIK, J. - SLAVKOVSKY, P. (eds.) 1995. Encyklopedia ludovej kultury Slovenska I., II. Bratislava: VEDA.

BRENZINGER, M. (ed.) 2007. Language diversity Endangered. Berlin- New York: Mouton de Gruyter.

DIVICANOVA, A., (ed.) 1996. Atlas ludovej kultury Slovakov v Madarsku - A magyarorszagi szlovakok nepi kulturajanak atlasza, Bekesska Caba: VUSM.

DIVICANOVA, A. 1999. Jazyk, kultura, spolocenstvo. Bekesska Caba: VUSM.

Elements of nationality affiliation of the population, 2011 - Bekescsaba, 2017, Available online: http://www.ksh.hu/nepszamlalas/tables_regional_04, (21.11.2017).

FAY, B. 2002. Soucasna filosofie socialnich vied. Multikulturni pristup, Praha:.SLON.

FEDIC, D. 2014. Analysis of Huncokars Dialect. In Ethnologia Actualis, Vol. 14, no. 2, pp. 105-114, ISSN 1339-7834.

FILADELFI, S. 2012. Slovenska mensina v krajinach byvaleho Uhorska v obdobi 1711 - 1918. In Klaudyan: internetovy casopis pro historickou geografii a environmentalni dejiny. Internet Journal of Historical Geography and Environmental History. Vol. 8-9, No. 1, pp. 26-42. Available online: http://www.klaudyan.cz, (21.11.2017).

FINDOR, A. 2005. Co je ,identita“? In Teoreticke pristupy k identitam a ich prakticke aplikacie. Zbornik zo seminara, Bratislava, pp. 43-51.

FISCHMAN, J. A. 1991. Reversing Language Shift. Theoretical and Empirical Foundations od Assistance to Threatened Language. ClevedonPhiladelphia_Adelaide: Multilingual Matters Ltd.

GOMBOS, J. 2005. Slovaci v Bekesskej zupe po skonceni tureckych vojen a uzavreti mieru v Karlovci. In UHRINOVA, A. - ZILAKOVA, M. (eds.). Pouzivanie slovenskeho jazyka v Bekesskej zupe. Bekesska Caba: VUSM, pp. 13-23.

CHRASTINA, P. 2006. Vyvoj vyuzitia kulturnej krajiny na severovychodnom okraji Bakonskeho lesa (obce Cafar, Cerna a Jasc). In DIVICANOVA, A. - TOTH, A., J. UHRINOVA, A., (eds.). Kultura, jazyk a historia Slovakov v Madarsku: materialy z jubilejnej interdisciplinarnej medzinarodnej vedeckej konferencie z prilezitosti 15 . vyrocia zalozenia Vyskumneho ustavu Slovakov v Madarsku. Bekesska Caba: VUSM, pp. 344-357.

CHRASTINA , P. 2009. Vnimanie krajiny v minulosti - historicka krajina slovenskej enklavy Bekesska Caba dnes. In Historicka geografie, Vol. 35, No. 1, pp. 79-86.

CHRASTINA , P. 2012. Pivnica : krajina - clovek - kultura - slovenske enklavy v srbskej Backe. In AMBRUS, I., M. (ed.). Svedectva slovenskeho dolnozemskeho bytia: aspekty zo slovenskej dolnozemskej kulturnej historie a kulturnej antropologie. Zbornik prac $\mathrm{z}$ rovnomenneho medzinarodneho seminara, ktory sa konal v Nadlaku 16. - 17. marca 2012. Nadlak: Ivan Krasko, pp. 187-201.

XLinguae, Volume 11, Issue 4, October 2018, ISSN 1337-8384, eISSN 2453-711X 
JANCOVIC, J. 2017. Tri storocia Slovakov v Bekesskej Cabe. In Slovak v Madarsku. Available online: http://www.oslovma.hu/index.php/sk/historia/164-historia1historia1/1348-tri-storoia-slovakov-v-bekeskej-abe, (21.11.2017).

IVANISCHEVA, O. 2016. Culture phenomena: lexicographical description issues. In XLinguae, Vol. 6, No. 2, pp. 73-89, ISSN 1337-8384.

KMET, M. 2013. Historiografia dolnozemskych Slovakov v prvej polovici 20. storocia. Krakow: Spolok Slovakov v Polsku.

KMET, M. 2010. Historiografia dolnozemskych Slovakov v 19. storoci. Bekesska Caba: VUSM.

KMET, M. 2011. Na margo problematiky mytov a stereotypov o Dolnej zemi v slovenskom kulturnom prostredi. In KOVACOVA, A. (ed.). Identita, historia a kultura. Budapest - Bekesska Caba: VUSM, pp. 50-63.

KMET, M. 2012. Kratke dejiny dolnozemskych Slovakov. Nadlak: Ivan Krasko.

KOKAISL, P. et. al. 2014. Po stopach Slovaku ve vychodni Evrope. Polsko, Ukrajina, Madarsko, Rumunsko, Srbsko, Chorvatsko a Cerni Hora. Praha: Nostalgie.

KRAUSS, M. 1992. The world's language in crisis. In Language, Vol 68, No. 1, pp. 4-10, ISSN 0097-8507.

AMBROZY, M. - KRALIK, R. - MARTIN, J. G. 2017. Determinism vs freedom: Some ethics-social implications $=$ Determinismo vs libertad: Algunas implicaciones etico-sociales. In XLinguae, Vol. 10, No. 4, pp. 48-57. ISSN 1337-8384.

KONDRLA, P. - KRALIK, R. 2016. Authentic being and moral conscience. In European Journal of Science and Theology. Vol. 12, No. 4, pp. 155-164. ISSN 18410464.

KOVACOVA, A. 2014. Po stopach slovenskej minulosti Budapesti. Budapest Bekesska Caba: VUSM.

KOVACOVA, A. 2011. Z historie pestianskeho slovenskeho evanjelickeho a katolickeho cirkevneho zivota a kultury. In Cirkevna kultura Slovakov v Madarsku, VUSM, Bekesska Caba, pp. 78-109.

KRECH, D. - CRUTCHFIELD, R., S. - BALLACHEY, E., L. 1968. Clovek v spolocnosti. Bratislava: Vydavatelstvo Slovenskej akademie vied.

LENOVSKY, L. 2005. Identity: (Today) a commodity among others (?). In Filozofia, Vol. 60, No. 7, pp. 536-541.

LENOVSKY, L. 2017. Nasi vo svete - Slovaci juzne od hranice Slovenska II. Nădlac: Vydavatelstvo Ivan Krasko.

LENOVSKY, L. 2016. Nasi vo svete - Slovaci juzne od hranice Slovenska I. Nădlac: Vydavatelstvo Ivan Krasko.

National data 2017. 2017. Available online: https://www.ksh.hu/?lang=en (20.11.2017).

SLOBODOVA NOVAKOVA, K. 2014. Study Possibilities of Present-Day Ethnic Revitalization of German Woodsmen in the Little Carpathians. In Ethnologia Actualis : the Journal of Ethnographical Research. Vol. 14, No. 2, pp. 97-108. ISSN 13397834.

SLOBODOVA NOVAKOVA, K. 2017. Partnersky a eroticky zivot v specificky izolovanom horskom prostredi (na priklade sposobu zivota nemeckych drevorubacov v Malych Karpatoch). In CIHAL, P. (ed.). Erotika v lidove kulture. Uherske Hradiste: Slovacke muzeum v Uherskem Hradisti, pp. 67-78, ISBN 978-80-87671-33-7.

PAPUCEK, G. - BALAZOVA, E. 2001. Madarsko. In Sprievodca slovenskym zahranicim, BARTALSKA, L. (ed.), Bratislava: Dom zahranicnych Slovakov, pp. 153-178.

KONDRLA, P. - PAVLIKOVA, M. 2016. From formal ethics to existential ethics. In European Journal of Science and Theology. Vol. 12, No. 3 (2016), pp. 101-111. ISSN 1841-0464. 
Populatia dupa etnie la recensamintele, 2017. Available online: http://www.insse.ro/cms/files/RPL2002INS/vol4/tabele/t1.pdf (20. 11.2017).

Population by ethnicity, by towns/municipalities, 2011 Census, 2017. Available online:

http://www.dzs.hr/Eng/censuses/census2011/results/htm/E01_01_04/E01_01_04_zup 16.html, (20.11.2017).

REERSHEMIUS, G. 2009. Post- Vernacular Language Use on a Low German Linguistic Community. In Journal of German Linguistic, Vol 21, No. 2, pp. 131-147, ISSN 1470-5425.

РЕЗУЛТАТИ ПОПИСА СТАНОВНИШТВА, ДОМАЋИНСТАВА И СТАНОВА У РЕПУБЛИЦИ СРПСКОЈ 2013 ГОДИНЕ, децембар 2016. 2017. Available online:

http://pod2.stat.gov.rs/ObjavljenePublikacije/Popis2011/Nacionalna\%20pripadnost-

Ethnicity.pdf, (20.11.2017).

SATAVA, L. 1994. Narodnostni mensiny v Evrope. Encyklopedicka prirucka, Praha: Ivo Zelezny.

SATAVA, L. 2013. Etnicita a jazyk. Teorie, praxe, trendy: citanka textu, Brno: Tribun EU.

SATAVA, L. 2017. „Novi mluvci“ v kontextu mensinovych jazyku v Evrope a revitalizacnich snah. In Narodopisni revue, Vol. 27, No. 4, pp. 323-330. ISSN 08628351.

STEFANKO, O. 2001. Rumunsko. In Sprievodca slovenskym zahranicim, BARTALSKA, L., (ed.), Bratislava: Dom zahranicnych Slovakov, pp. 233-252.

SUTAJ, S. 2005. Ceskoslovenske statne obcianstvo Slovakov presidlenych z Madarska. In Clovek a spolocnost. Internetovy casopis pre povodne, teoreticke a vyskumne studie z oblasti spolocenskych vied. Vol. 8, No. 1, Available online: http://www.saske.sk/cas/archiv/1-2005/sutaj.html, (20.11.2017).

Tri typy slovenskych narodnostnych skol v Madarsku. Celostatna slovenska samosprava v $\quad$ Madarsku, 2015. Available online: http://www.slovaci.hu/index.php/sk/kolstvo/65-tri-typyslovensk-ch-narodnostn-ch-k1-v-ma-arsku

TUSKOVA, T. 2016. Slovensky jazyk v univerzitnom bilingvalnom prostredi. Bekesska Caba: Vyskumny ustav Slovakov v Madarsku.

TUSKOVA, T. 2010. Obraz o kulturnych atitudach mladych Slovakov v madarskom prostredi. In Jazyk a komunikacia $\mathrm{v}$ suvislostiach III. Bratislava: Univerzita Komenskeho, pp. 227-232.

TUSKOVA, T. 2011. Ciastkove vysledky vyskumu v kruhu mladych Slovakov v madarskom prostredi. In Profesorul Corneliu Barborica la a 80-a Aniversare, ANOCA, M., D., (ed.). Bucurest: Univerzita v Bukuresti, pp. 263-275.

UHRINOVA, A. 2008. Najdolezitejsie faktory zachovania slovenskeho jazyka v Madarsku. In Slovencina $\mathrm{v}$ mensinovom prostredi. Studie $\mathrm{z}$ II. medzinarodnej konferencie Vyskumneho ustavu Slovakov v Madarsku, HORNOKOVA, A. - TOTH, A., J., (eds.), Bekesska Caba: VUSM, pp. 71-90.

UHRINOVA, A. 2006. O projekte Slovensky jazyk v Madarsku. In Kultura, jazyk a historia Slovakov $\mathrm{v}$ Madarsku: materialy $\mathrm{z}$ jubilejnej interdisciplinarnej medzinarodnej vedeckej konferencie z prilezitosti 15. vyrocia zalozenia Vyskumneho ustavu Slovakov v Madarsku, DIVICANOVA, A. - TOTH, A., J. - UHRINOVA, A. (eds.), Bekesska Caba: VUSM, pp. 226-230.

Words: 7688

Characters: 57370 (31,87 standard pages)

XLinguae, Volume 11, Issue 4, October 2018, ISSN 1337-8384, eISSN 2453-711X 
prof. PhDr. Ladislav Lenovský, PhD.

Department of Ethnology and World Studies

Faculty of Arts

Ss. Cyril and Methodius University in Trnava

Nám. J. Herdu 2, Trnava

Slovak Republic

ladislav.lenovsky@ucm.sk 